\title{
EFFECT OF HOUSING SYSTEM ON EGG QUALITY IN LAYING HENS*
}

\author{
Lidia Lewko, Ewa Gornowicz \\ Department of Animal Genetic Resources Conservation, National Research Institute \\ of Animal Production, Zakrzewo, Poznańska 18, 62-070 Dopiewo, Poland
}

\begin{abstract}
The aim of the study was to evaluate the quality of eggs from hybrids of laying hens of selected Polish breeding strains depending on their housing system. Analysis was made of eggs from KA62, KA-42, KA-68 and KA-48 hybrids housed in three systems: cage, litter and free range. One hundred eggs, randomly chosen from each experimental group between 34 and 36 weeks of age, were evaluated for a set of physical characteristics such as weight of egg and egg fraction, percentage of main egg fractions, egg shape index, air cell height, albumen height and pH, Haugh units, yolk colour and $\mathrm{pH}$, as well as shell colour, thickness, density and deformation. Caged birds produced the heaviest eggs $(61.06 \mathrm{~g})$ with the lowest shape index $(77.86 \%)$, lightest shell $(39.86)$ and highest percentage of albumen $(57.04 \%)$ and yolk $(29.89 \%)$ in the egg. The most favourable quality traits of albumen from the analysed eggs, i.e. greatest height $(5.00 \mathrm{~mm})$ and Haugh units (69.70) were characteristic of egg albumen from hens raised on litter. Shell quality analysis showed that the eggs of free-range birds were characterized by the highest weight of shell $(5.76 \mathrm{~g})$, which had the greatest thickness $(360.14 \mu \mathrm{m})$ and density $\left(81.01 \mathrm{mg} / \mathrm{cm}^{2}\right)$. Detailed analysis of the physical characteristics of eggs from the hybrids of laying hens revealed significant $(P \leq 0.05)$ differences depending on the housing system. The eggs of caged layers showed many characteristics desired by processors. Meanwhile, the eggs of hens kept on litter were characterized by dietetic properties that could meet specific needs of the consumers.
\end{abstract}

Key words: housing, egg, quality, physical characteristics

Different housing systems of laying hens continue to cause controversy among researchers, producers, environmentalists and consumers (Sokołowicz and Krawczyk, 2009). The matter of priority is the effect of these systems on the health of birds and their freedom to express natural behaviour. However, it is not easy to assess if a housing system provides for good health and basic ethological and behavioural needs of birds. These systems influence, directly and indirectly, not only the behaviour, productivity and health of birds, but also the quality of their eggs (Abrahamsson and Tauson, 1995; Tauson, 2005).

In recent years, organic farming has become increasingly popular in Europe, including Poland. There is a return to traditional methods of poultry housing, with

\footnotetext{
*This study was supported by the Ministry of Agriculture and Rural Development, project no. 5112.3 .
} 
access to open spaces, fresh air and sunshine, and feeding based on natural and minimally processed feeds (Krawczyk and Gornowicz, 2010). However, it is much more expensive to obtain products (including hen's eggs) using certified methods compared to conventional methods. This is due to factors such as longer rearing period, higher feed consumption, lower productivity and lower fertility. In wealthy Western European countries, organic farming of layers accounts for $10 \%$ of total layer production. In Poland, it is still of marginal significance and does not exceed 1\%. Egg production in Poland is mainly based on cage housing of hens. Many studies have shown this is the most economical form of producing good-quality eggs. However, the Council Directive 1999/74/EC states that the sale of eggs laid by hens from the conventional cage system will be limited or even prohibited from 1 January 2012. Polish egg producers are making intense efforts to extend the use of conventional cages by 5 years and not allow for products from the cage system to be discriminated against.

Research is underway to develop environment-friendly production technologies that meet the expectations of middle-class consumers while reconciling animal product safety and quality with modest prices (Górski et al., 2002; Sobczak, 2008).

Hen's egg is considered one of nature's most valuable and basic food products (Anton et al., 2006; Sparks, 2006). Consumers are more and more interested in egg quality, which means that ensuring high quality of poultry products takes on increasing significance. Considering that societies grow increasingly wealthy and healthconscious, the quality of food products will continue to be the focus of attention of consumers and producers as well as a challenge for science. For this reason, in this competitive age efforts are taken to make premium products that guarantee quality and safety. This can be achieved by providing animals with optimum husbandry conditions and quality feeds containing all the essential nutrients that guarantee high productivity and good quality of eggs (Krawczyk and Calik, 2006).

The aim of the study was to evaluate the quality of eggs from hybrids of laying hens of selected Polish breeding strains depending on their housing system.

\section{Material and methods}

Analysis was made of eggs from a flock of layer hybrids, which were divided into three experimental groups kept in different husbandry systems: cage, litter and free range. Each group contained a total of 16 birds, with 4 KA-62, KA-42, KA68 and KA-48 hybrids per group. The experimental hybrids, derived from crossing strains K-66, K-44 (Rhode Island Red), A-88 and A-22 (Rhode Island White), should exhibit many traits characteristic of general-purpose hens. They are intended mainly for egg production in litter confinement and backyard systems.

Hybrids were reared (Experimental Station of the National Research Institute of Animal Production in Duszniki, Poland) to 16 weeks of age in the litter confinement system under the same environmental and feeding conditions. At 16 weeks, birds were assigned to experimental groups in confinement (cage, litter) and on free range. Hens started to lay eggs between 18 and 20 weeks of age. 
From 20 weeks of age, all birds received a diet containing $17.5 \%$ crude protein, 11.7 MJ metabolizable energy, 3.6\% fibre, $0.82 \%$ lysine, $0.36 \%$ methionine, $3.6 \%$ calcium and $0.34 \%$ available phosphorus. Free-range birds were unable to supplement their diet with other feeds because they were raised on a $15-\mathrm{cm}$ layer of compacted river sand, but they had free access to feed and water. Feeders and drinkers were located on free range and in a wooden shed, which provided shelter during rain and at night.

Birds on litter (chopped straw) and those in cages were kept in a confinement house under controlled climate conditions. The lighting regime resembled natural outdoor conditions of free-range hens. The experimental production was carried out during the summer (from May to the end of September). Stocking density for hens maintained on litter and on free range was $8.5 \mathrm{~m}^{2} /$ bird. Two layers were housed in each cage with $0.75 \mathrm{~m}^{2}$ of floor area per bird.

One hundred eggs, randomly chosen from each experimental group between 34 and 36 weeks of age, were evaluated for a set of physical characteristics. Eggs for analysis were collected in September from hens after peak egg production. During this period, egg production was $87.1 \%$ in the cage system, $86.6 \%$ on litter and $85.9 \%$ on free range. At the end of 34 weeks, all the eggs were collected every morning. Eggs collected over two days were sent to a laboratory until 100 eggs were obtained from each group. Egg quality was analysed in a laboratory of the National Research Institute of Animal in Zakrzewo immediately after the eggs were brought from the farm.

The EQM system (Technical Services and Supplies Limited, England) was used to measure egg weight and egg fractions (g), height of thick albumen (mm), Haugh units (HU), yolk weight (g), yolk colour (Roche scale), shell colour (\% light reflectance), and shell density $\left(\mathrm{mg} / \mathrm{cm}^{2}\right)$. Air cell height was measured using the ovolux (handheld egg candling lamp) and a millimeter-scale ruler. Egg shape index (\%) was calculated by dividing egg length by egg width. Measurements were made to the nearest $0.5 \%$ with a Shape-Meter (B.V. Apparatenfabriek Van Doorn, De Bilt, The Netherlands), scaled $65-85 \%$. Shell deformation was measured instrumentally (Marius N.V., Utrecht, The Netherlands) accurate to $1 \mu \mathrm{m}$. Shell thickness without inner and outer shell membranes was measured using a micrometer (accuracy $1 \mu \mathrm{m}$, Mitutoyo, Japan). A Metler Toledo (Switzerland) $\mathrm{pH}$ meter was used to determine the concentration of hydrogen ions $(\mathrm{pH})$ in albumen and yolk.

Statistical analysis of egg quality traits in the experimental populations of birds was performed using analysis of variance (means, standard deviations, coefficient of variation) and differences $(\mathrm{P} \leq 0.05)$ were shown using Duncan's multiple range test from the Statistica 6.0 package.

\section{Results}

Caged birds were characterized by the heaviest eggs (61.06 g) and the lowest shape index $(77.86 \%)$, with statistically significant $(\mathrm{P} \leq 0.05)$ differences. Depending 
on the housing system, highly significant differences $(\mathrm{P} \leq 0.05)$ were found for egg weight, egg shape index, air cell height, and albumen and shell content. Eggs from caged birds had the highest percentage of albumen and yolk in the egg, with a difference of $0.87 \%$ and $0.58 \%$, respectively. Shell percentage ranged from 8.77 (litter) to $9.93 \%$ (free range) (Table 1).

Table 1. Physical characteristics and percentage composition of eggs according to hen housing system

\begin{tabular}{|c|c|c|c|c|}
\hline \multirow{2}{*}{ Characteristic } & & \multicolumn{3}{|c|}{ Housing system } \\
\hline & & litter & cage & free range \\
\hline \multirow[t]{3}{*}{ Egg weight (g) } & $\overline{\mathrm{x}}$ & $56.35 \mathrm{~b}$ & $61.06 \mathrm{a}$ & $57.93 \mathrm{ab}$ \\
\hline & $\mathrm{s}$ & 5.06 & 2.98 & 3.36 \\
\hline & $\mathrm{V}$ & 9.0 & 4.9 & 5.8 \\
\hline \multirow[t]{3}{*}{ Egg shape index (\%) } & $\overline{\mathrm{x}}$ & 79.00 & 77.86 & 79.29 \\
\hline & $\mathrm{s}$ & 2.52 & 2.12 & 3.64 \\
\hline & $\mathrm{V}$ & 3.2 & 2.7 & 4.6 \\
\hline \multirow[t]{3}{*}{ Air cell height (mm) } & $\overline{\mathrm{X}}$ & 3.86 & 3.71 & 3.57 \\
\hline & $\mathrm{s}$ & 0.38 & 0.49 & 0.53 \\
\hline & $\mathrm{V}$ & 9.8 & 13.1 & 15.0 \\
\hline \multirow[t]{3}{*}{ Albumen content $(\%)$} & $\overline{\mathrm{x}}$ & 56.74 & 57.04 & 56.17 \\
\hline & $\mathrm{s}$ & 4.10 & 2.58 & 1.97 \\
\hline & $\mathrm{v}$ & 7.2 & 4.5 & 3.5 \\
\hline \multirow[t]{3}{*}{ Yolk content $(\%)$} & $\overline{\mathrm{x}}$ & 29.75 & 29.89 & 29.31 \\
\hline & $\mathrm{s}$ & 0.03 & 2.24 & 1.69 \\
\hline & $\mathrm{v}$ & 10.2 & 7.5 & 5.8 \\
\hline \multirow[t]{3}{*}{ Shell conten $(\%)$} & $\overline{\mathrm{x}}$ & $8.77 \mathrm{~b}$ & $9.03 \mathrm{ab}$ & $9.93 \mathrm{a}$ \\
\hline & $\mathrm{s}$ & 0.90 & 0.73 & 0.88 \\
\hline & $\mathrm{V}$ & 10.2 & 8.0 & 8.8 \\
\hline
\end{tabular}

$\overline{\mathrm{x}}-$ mean.

$\mathrm{s}-$ standard deviation.

$\mathrm{v}$ - coefficient of variation.

$\mathrm{a}, \mathrm{b}$ - different letters denote statistically significant differences, $\mathrm{P} \leq 0.05$.

Eggs laid by caged birds were characterized by yolks with the highest weight (18.20 g) and $\mathrm{pH}$ value (7.06) and the lightest colour (7.04). All physical characteristics of egg yolk showed significant differences $(\mathrm{P} \leq 0.05)$ (Table 2$)$.

The most favourable quality traits of albumen from the analysed eggs, i.e. greatest height $(5.00 \mathrm{~mm})$ and Haugh units (69.70) were characteristic of egg albumen from hens raised on litter. Albumen weight ranged from $31.95 \mathrm{~g}$ (litter) to $34.89 \mathrm{~g}$ (cages). Measurement of albumen $\mathrm{pH}$ showed the highest values for eggs from birds kept on litter. Significant differences $(\mathrm{P} \leq 0.05)$ were also found for all physical characteristics of egg albumen (Table 3 ). 
Table 2. Physical characteristics of egg yolk according to hen housing system

\begin{tabular}{lc|c|c|c}
\hline \multirow{2}{*}{ Characteristic } & & \multicolumn{3}{|c}{ Housing system } \\
\cline { 3 - 5 } & & litter & cage & free range \\
\hline Yolk weight (g) & $\overline{\mathrm{x}}$ & 16.79 & 18.20 & 16.95 \\
& $\mathrm{~S}$ & 2.49 & 0.94 & 0.99 \\
& $\mathrm{v}$ & 14.8 & 5.2 & 5.8 \\
$\mathrm{pH}$ value & $\overline{\mathrm{x}}$ & $6.95 \mathrm{ab}$ & $7.06 \mathrm{a}$ & $6.92 \mathrm{~b}$ \\
& $\mathrm{~S}$ & 0.07 & 0.09 & 0.15 \\
& $\mathrm{~V}$ & 1.0 & 1.3 & 2.1 \\
Colour (La Roche scale) & $\overline{\mathrm{x}}$ & $8.00 \mathrm{a}$ & $7.04 \mathrm{~b}$ & $7.89 \mathrm{ab}$ \\
& $\mathrm{S}$ & 1.29 & 1.22 & 1.60 \\
& $\mathrm{v}$ & 16.1 & 29.3 & 30.3 \\
\hline
\end{tabular}

$\overline{\mathrm{x}}-$ mean.

$\mathrm{s}-$ standard deviation.

$\mathrm{v}$ - coefficient of variation.

$\mathrm{a}, \mathrm{b}$ - different letters denote statistically significant differences, $\mathrm{P} \leq 0.05$.

Table 3. Physical characteristics of egg albumen according to hen housing system

\begin{tabular}{lc|c|c|c}
\hline \multirow{2}{*}{ Characteristics } & & \multicolumn{3}{c}{ Housing system } \\
\cline { 3 - 5 } & & litter & cage & free range \\
\hline Albumen weight $(\mathrm{g})$ & $\overline{\mathrm{x}}$ & 31.95 & 34.89 & 32.54 \\
& $\mathrm{~s}$ & 3.47 & 3.17 & 2.19 \\
& $\mathrm{v}$ & 10.9 & 9.1 & 6.7 \\
$\mathrm{pH}$ value & $\overline{\mathrm{x}}$ & $9.33 \mathrm{a}$ & $9.07 \mathrm{~b}$ & $9.25 \mathrm{a}$ \\
& $\mathrm{s}$ & 0.16 & 0.12 & 0.14 \\
& $\mathrm{v}$ & 1.7 & 1.3 & 1.5 \\
Albumen height $(\mathrm{mm})$ & $\overline{\mathrm{x}}$ & 5.00 & 4.49 & 4.07 \\
& $\mathrm{~s}$ & 1.05 & 0.81 & 1.57 \\
& $\mathrm{v}$ & 21.0 & 17.9 & 38.5 \\
& $\overline{\mathrm{x}}$ & 69.70 & 62.80 & 58.64 \\
& $\mathrm{~s}$ & 8.07 & 7.99 & 13.43 \\
& $\mathrm{v}$ & 11.6 & 12.7 & 22.9 \\
\hline
\end{tabular}

$\overline{\mathrm{x}}-$ mean.

$\mathrm{s}-$ standard deviation.

$\mathrm{v}-$ coefficient of variation.

$\mathrm{a}, \mathrm{b}$ - different letters denote statistically significant differences, $\mathrm{P} \leq 0.05$.

Comprehensive quality analysis of shells revealed that the eggs of free-range birds had not only the highest shell weight $(5.76 \mathrm{~g})$ but also the highest shell thickness $(360.14 \mu \mathrm{m})$ and density $\left(81.01 \mathrm{mg} / \mathrm{cm}^{2}\right)$, with the smallest shell deformation $(20 \mu \mathrm{m})$. The lightest shells came from caged layers (39.86). When analysing shell 
quality traits depending on the housing system, statistically significant differences were found for all the parameters (Table 4).

Table 4. Physical characteristics of egg shell according to hen housing system

\begin{tabular}{|c|c|c|c|c|}
\hline \multirow{2}{*}{\multicolumn{2}{|c|}{ Shell characteristics }} & \multicolumn{3}{|c|}{ Housing system } \\
\hline & & litter & cage & free range \\
\hline \multirow[t]{3}{*}{ Weight $(\mathrm{g})$} & $\overline{\mathrm{X}}$ & 4.93 & 5.50 & 5.76 \\
\hline & $\mathrm{s}$ & 0.51 & 0.33 & 0.71 \\
\hline & $\mathrm{v}$ & 10.4 & 5.9 & 12.3 \\
\hline \multirow[t]{3}{*}{ Thickness $(\mu \mathrm{m})$} & $\overline{\mathrm{X}}$ & $317.71 \mathrm{~b}$ & $333.71 \mathrm{ab}$ & $360.14 \mathrm{a}$ \\
\hline & $\mathrm{s}$ & 36.08 & 18.03 & 36.18 \\
\hline & $\mathrm{V}$ & 11.4 & 5.4 & 10.0 \\
\hline \multirow[t]{3}{*}{ Deformation $(\mu \mathrm{m})$} & $\overline{\mathrm{x}}$ & $27.33 \mathrm{a}$ & $22.76 \mathrm{ab}$ & $20.00 \mathrm{~b}$ \\
\hline & $\mathrm{s}$ & 6.39 & 1.41 & 4.45 \\
\hline & $\mathrm{v}$ & 23.4 & 6.2 & 22.2 \\
\hline \multirow[t]{3}{*}{ Density $\left(\mathrm{mg} / \mathrm{cm}^{2}\right)$} & $\overline{\mathrm{x}}$ & $70.77 \mathrm{~b}$ & $74.88 \mathrm{ab}$ & $81.01 \mathrm{a}$ \\
\hline & $\mathrm{s}$ & 6.68 & 5.25 & 7.90 \\
\hline & $\mathrm{v}$ & 9.4 & 7.0 & 9.8 \\
\hline \multirow[t]{3}{*}{ Colour (pts) } & $\overline{\mathrm{X}}$ & 35.43 & 39.86 & 36.29 \\
\hline & $\mathrm{s}$ & 7.76 & 8.93 & 5.53 \\
\hline & $\mathrm{v}$ & 21.9 & 22.4 & 15.2 \\
\hline
\end{tabular}

$\overline{\mathrm{x}}-$ mean.

$\mathrm{s}-$ standard deviation.

$\mathrm{v}-$ coefficient of variation.

$\mathrm{a}, \mathrm{b}$ - different letters denote statistically significant differences, $\mathrm{P} \leq 0.05$.

\section{Discussion}

Egg weight is the most important physical characteristic of hen's eggs perceived by the consumer. It is also the basic quality characteristic included in egg marketing regulations, which classify eggs into four weight categories (Commission Regulation (EC) No 589/2008). For the reasons stated above, egg weight is the essential selection trait in layer breeding and one of the most important traits in the breeding of general-purpose hens.

When comparing quality traits of ISA Brown layers raised in two systems (litter and cage), Voslářová et al. (2006) found that markedly heavier eggs were produced by caged layers $(53.40 \mathrm{~g})$.

Using the same study material, Dukić-Stojčić et al. (2009) compared the quality of eggs from caged layers and those from restricted and free-range layers and found that heavier eggs (66.74 g) with a higher shape index (75.29) as well as thicker and lighter shell $(373.60 \mu \mathrm{m}$ and 3.05 , respectively) were laid by caged hens. The findings reported above for egg weight confirm the results of our study, in which the weight of eggs from caged hens was also higher, on average by $4.71 \mathrm{~g}$ in relation to 
eggs from litter-reared hens and by $3.13 \mathrm{~g}$ in relation to eggs from free-range birds. The only significant $(\mathrm{P}<0.05)$ difference in egg weight was between the cage and litter systems. Our study showed that heaviest eggs with the highest albumen and yolk weight were produced by caged layers.

The results concerning the effect of housing system on the weight and morphological composition of eggs are not consistent. Pištěková et al. (2006) showed that heaviest eggs with the highest albumen and yolk weight were laid by hens in the litter system. Meanwhile, Van Den Brand et al. (2004) reported that free-range layers produced heavier eggs (56.41 g) with higher shape index (75.44) and greater percentage of albumen (59.05\%) and shell (12.64\%) in egg weight. Similarly, in our study the highest egg shape index (79.29) was characteristic of eggs from free-range birds, followed by eggs from the litter system (79.00), with statistically significant differences $(\mathrm{P}<0.05)$ in relation to the cage system.

The main determinant of table egg quality is freshness, which is evaluated based on air cell size, albumen thinning (expressed by albumen height and Haugh units) and $\mathrm{pH}$ value (Lewko and Gornowicz, 2009). Of the above parameters, air cell height is the easiest to evaluate quickly. For this reason, the value of this parameter has for many years been the basic criterion used to evaluate marketed eggs for freshness. Many world standards, including EU egg marketing standards currently used in Poland, grade eggs for quality according to air cell height. In class A eggs, air cell height may not exceed $6 \mathrm{~mm}$; however, for eggs to be marketed as extra, it may not exceed 4 mm (Commission Regulation (EC) No 589/2008).

From the moment an egg is laid, as a result of physico-chemical changes known as egg aging, the shell loses its natural protective ability, whereas water and gases begin to move both within the egg content and between the internal and external environments of the egg. Water evaporation of the egg is determined by physiological factors such as shell permeability, shell pore diameter, and the rate at which mucin covering dries and breaks. It was also shown that water loss is more rapid in small eggs that have more surface area in relation to volume.

In our study, we analysed eggs that were basically fresh, because the evaluation was performed within $48 \mathrm{~h}$ of oviposition. It was assumed that changes in the above parameters, related to water and gas movement in egg contents, were determined by environmental factors associated with the housing system. All the eggs analysed were qualified as Class A "Extra" based on the values ranging from $3.57 \mathrm{~mm}$ to 3.86 $\mathrm{mm}$.

When analysing egg freshness based on air cell height, we found the lowest value in eggs produced by free-range hens. This value was $0.29 \mathrm{~mm}$ lower in relation to eggs from caged hens and $0.14 \mathrm{~mm}$ lower in relation to litter-reared hens. Differences in the values of this trait were statistically significant $(\mathrm{P}<0.05)$ between the three housing systems studied. Meanwhile, Calik et al. (2003) and Biesiada-Drzazga and Janocha (2009), who compared freshness of eggs from layers in the litter and cage systems showed no significant effect of housing system (cages/litter) on air cell height. Similarly to our findings, Biesiada-Drzazga and Janocha (2009) reported lower values for eggs from caged hens: $3.2 \mathrm{~mm}$ (Hy-Line Brown) and $3.5 \mathrm{~mm}$ (Tetra SL). On the other hand, Calik et al. (2003) showed for brown-shelled eggs produced 
by 32-week-old Hy-Line Brown layers that this trait had a very low and desirable value of 1.62 to $1.76 \mathrm{~mm}$. In all the studies discussed in the present work, air cell height did not exceed $4.00 \mathrm{~mm}$, which means that all the eggs were Class "Extra" regardless of the hen housing system.

As noted before, the other important determinants of egg freshness (and thus quality) are parameters of albumen. Albumen quality increases with increasing height and decreasing area after breaking open the albumen. Egg weight and height of thick albumen are used to calculate Haugh units. Desirable values exceed 60 units. In our study, these values were obtained for eggs from hens reared on litter (69.7) and in cages (62.8). The albumen of eggs from free-range hens failed to achieve the expected quality (58.64). The differences were statistically significant $(\mathrm{P}<0.05)$ for the three housing systems studied.

When analysing albumen quality characteristics, Dukić-Stojčić et al. (2009) showed lower albumen height $(7.96 \mathrm{~mm})$ and Haugh units (87.08) for eggs from caged birds. The analysed parameters reached the values desired by consumers but were significantly lower than those obtained for the eggs of free-range hens or hens with limited outdoor access. These authors showed that housing system has an effect on albumen quality traits $(5.94 *$ and $3.163 *$, respectively), although the age of birds influenced these parameters to a much greater extent $\left(18.76^{* * *}\right.$ and $7.465^{* *}$, respectively). Likewise, Van Den Brand et al. (2004) provided evidence that eggs from free-range birds had the highest albumen after breaking open the albumen (6.04 $\mathrm{mm}$ ) as well as the highest $\mathrm{pH}$ value (8.16). In our study, the concentration of hydrogen ions in albumen and yolk differed significantly $(\mathrm{P}<0.05)$ in eggs from caged, litter-reared and free-range hens. The difference in albumen $\mathrm{pH}$ did not concern hens raised on litter. As in studies by other authors, albumen $\mathrm{pH}$ was high and conducive to the growth of microorganisms potentially penetrating the egg.

Pištěková et al. (2006), who performed a comparative analysis of egg quality in ISA Brown hens maintained in cages and on litter showed that the highest percentage of yolk (26.34\%) and shell (12.34\%) was characteristic of eggs from caged birds. The same authors also demonstrated that eggs with heaviest shells $(7.48 \mathrm{~g})$, highest shell deformation $(32.13 \mu \mathrm{m})$ and darkest yolk were produced by hens from the litter system. In our study, we obtained similar correlations for egg yolk percentage, shell deformation and yolk colour, but lower values for egg shell percentage (by $3.31 \%$ on average) and lower shell weight (by $2.55 \mathrm{~g}$ on average). In the present study, the most favourable shell quality traits, i.e. the highest shell weight $(5.76 \mathrm{~g})$, thickness $(360.14 \mu \mathrm{m})$ and density $\left(81.01 \mathrm{mg} / \mathrm{cm}^{2}\right)$, were characteristic of the eggs of free-range birds. These data are also consistent with the results of relevant studies obtained by Hidalgo et al., 2007, 2008; Nowak and Sobczak, 2005).

In conclusion, our detailed analysis of the physical characteristics of eggs from hybrids of laying hens showed significant $(\mathrm{P} \leq 0.05)$ differences depending on the housing system. In summing up, the eggs of caged layers could prove useful for the processing industry (e.g. for making egg products) due to their high weight and largest percentage of albumen with the most desired quality traits. Free-range hens produced eggs that showed many characteristics of desirable freshness and shells that had best quality parameters. 
From the consumer's point of view, the most desirable traits were characteristic of the eggs from hens raised on litter, because they had sought-after colour, thick shells and darkest yolks. This makes these hens most suitable for backyard systems as they could meet specific needs of the consumers.

\section{References}

A brahams s on P., T a u s o n R. (1995). Aviary systems and conventional cages for laying hens: effects on production, egg quality, health and bird location in three hybrids. Acta Agr. Scand., 45, 3: 191-203.

Anton M., Nau F., Nys Y. (2006). Bioactive egg components and their potential uses. World's Poultry Sci. J., 62: 429-438.

B i e s i a d a - D r z a z g a B., J a n o c h a A. (2009). Impact of hen breed and rearing system on the quality of eggs for consumption (in Polish). Food. Science. Technology. Quality, 3, 64: 67-74.

Calik J., P ołtowicz K., W ężyk S. (2003). Effect of housing system of laying hens and storage conditions of table eggs on their quality (in Polish). Wyniki Oceny Użytkowości Drobiu, 31: 57-62.

Dukić-S tojčić M., Perić L., Bjedov S., Milošević N. (2009). The quality of table eggs produced in different housing systems. Biot. Anim. Husbandry, 25 (5-6): 1103-1108.

Górski J., Wi tak B., B iesiada-Drzazga B. (2002). Analysis of production and economic results obtained in two laying periods of hens kept on litter or in batteries (in Polish). Rocz. Nauk. Zoot., Supl., 16: 103-108.

Hidalgo A., R os s i M., C le ri ci F., R atti S. (2008). A market study on the quality characteristics of eggs from different housing systems. Food Chem., 106, 3: 1031-1038.

Krawczyk J., Calik J. (2006). Egg quality in free-range hens. Pol. J. Nat. Sci., Supl., 3 (1): 433-438.

Krawczyk J., Gornowicz E. (2010). Quality of eggs from hens kept in two different free-range systems in comparison with a barn system. Arch. Geflügelk., 74 (3): 151-157.

Lew ko L., Gornowicz E. (2009). Egg albumen quality as affected by bird origin. J. Cent. Eur. Agric., 10, 4: 455-464.

N ow a k A., S o b c z a k J. (2005). Housing system of laying hens and consumers quality (in Polish). Proc. XVII Int. Poultry Symp., Kiekrz near Poznań, pp. 91-92.

Pištěková V., Hovorka M., Većerek V., Straková E., Suchý P. (2006). The quality comparison of eggs laid by laying hens kept in battery cages and in a deep litter system. Czech. J. Anim. Sci., 51: 318-325.

S o b c z a k J. (2008). The investigations of economic efficiency of consumers' eggs production under recommended keeping system for hens (in Polish). Probl. Inż. Roln., 3: 95-103.

S o k ołow i c z Z., K r a w c z y k J. (2009). Housing system of laying hens as a factor for sustainable dewelopment (in Polish). Zesz. Nauk. PTIE i PTG Oddz. w Rzeszowie, 11: 249-252.

S parks N.H.C. (2006). The hen's egg - is its role in human nutrition changing? World Poultry Sci. Assoc., 62: 308-315.

T a u s o n R. (2005). Management and housing systems for layers - effects on welfare and production. World Poultry Sci., 61: 477-490.

Van den Brand H., Parmentier H.K., Ke m p B. (2004). Effects of housing system (outdoor vs cages) and age of laying hens on egg characteristics. Brit. Poultry Sci., 45: 745-752.

Vos lář ová E., H a nzálek Z., V eč er ek V., Straková E., S u chý P. (2006). Comparison between laying hen performance in the cage system and the deep litter system on a diet free from animal protein. Acta Vet. Brno, 75: 219-225. 


\section{LIDIA LEWKO, EWA GORNOWICZ}

\section{System utrzymania ptaków jako czynnik ksztaltujący jakość jaj kur nieśnych}

\section{STRESZCZENIE}

Celem badań była charakterystyka cech jakości jaj pochodzących od wybranych krajowych mieszańców kur nieśnych w zależności od systemu chowu. Materiał badawczy stanowiły jaja pochodzące z jednolitego stada mieszańców kur nieśnych podzielonych na trzy grupy doświadczalne, z których każda utrzymywana była innym systemem chowu: w klatkach, na ściółce oraz na wybiegu. Każda grupa liczyła po 18 ptaków. Na wybranych losowo 100 jajach z każdej grupy doświadczalnej, w okresie od 34 . do 36. tygodnia życia kur, określono kompleks cech fizycznych (masa jaja i jego frakcja, procentowy udział głównych frakcji w jaju, indeks jaja, wysokość komory powietrznej, wysokość białka i jego pH, jednostki Haugha, barwa i pH żółtka, barwa, grubość, gęstość i odkształcenie elastyczne skorupy).

Wykazano, że ptaki utrzymywane w klatkach wyróżniały się najcięższymi jajami $(61,06$ g), o najmniejszym parametrze indeksu jaja $(77,86 \%)$ i najjaśniej wybarwionej skorupie $(39,86)$. Jaja pochodzące $\mathrm{z}$ tego chowu odznaczały się ponadto najwyższym procentowym udziałem białka $(57,04 \%)$ i żółtka $(29,89 \%)$ w jaju oraz najwyższą masą tych frakcji, wynoszącą odpowiednio 18,20 g i 34,89 g. Żółtka pochodzące od jaj pozyskanych systemem klatkowym charakteryzowały się największą wartością pH $(7,06)$ oraz najjaśniejszym wybarwieniem ukształtowanym na poziomie 7,04 . Najkorzystniejszymi cechami jakościowymi białka analizowanych jaj, tj. największą wysokością $(5,00 \mathrm{~mm})$, jednostkami Haugha $(69,70)$, a także najwyższą wartością pH $(9,33)$, wyróżniały się białka jaj kur utrzymywanych systemem ściółkowym. Analiza jakościowa skorup wykazała, że jaja ptaków utrzymywanych na wybiegu cechowały się największą masą skorupy $(5,76 \mathrm{~g})$, o największej jej grubości $(360,14 \mu \mathrm{m})$ i gęstości $\left(81,01 \mathrm{mg} / \mathrm{cm}^{2}\right)$.

Przeprowadzona szczegółowa charakterystyka cech fizycznych jaj analizowanych mieszańców kur nieśnych wykazała istotne różnice $(\mathrm{P} \leq 0,05)$ w zależności od systemu utrzymywania ptaków. Jaja niosek pochodzące z systemu klatkowego wyróżniały się wieloma cechami pożądanymi w przetwórstwie (duża masa jaja i jego poszczególnych frakcji). Z kolei, walorami mogącymi zaspokoić indywidualne potrzeby konsumenta (wysokie, zwarte białko po wybiciu i dobra skorupa) cechowały się jaja kur odchowywanych na ściółce. 